\title{
Water table fluctuations in the riparian zone: comparative results from a pan-European experiment
}

\author{
T.P. Burt ${ }^{\mathrm{a}, *}$, G. Pinay ${ }^{\mathrm{b}}$, F.E. Matheson ${ }^{\mathrm{a}, 1}$, N.E. Haycock ${ }^{\mathrm{c}}$, A. Butturini ${ }^{\mathrm{d}}$, J.C. Clement ${ }^{\mathrm{b}}$, \\ S. Danielescu ${ }^{\text {e }}$ D.J. Dowrick, M.M. Hefting ${ }^{f}$, A. Hillbricht-Ilkowska ${ }^{g}$, V. Maitre ${ }^{\text {h }}$ \\ ${ }^{a}$ Science Laboratories, Department of Geography, University of Durham, South Road, Durham DH1 3LE, UK \\ ${ }^{\mathrm{b}}$ ECOBIO, University of Rennes 1, F-35042 Rennes cedex, France \\ ${ }^{\mathrm{c}}$ Haycock Associates Ltd, 11 Edison Close, St., Albans AL4 ODE, UK \\ ${ }^{\mathrm{d}}$ Department of Ecology, University of Barcelona, SP-08028 Barcelona, Spain \\ ${ }^{\mathrm{e}}$ Department of Ecology, University of Bucharest, RO-76201 Bucharest, Romania \\ ${ }^{\mathrm{f}}$ Department of Plant Ecology and Evolutionary Biology, University of Utrecht, Utrecht 3508-TB, The Netherlands \\ ${ }^{\mathrm{g}}$ Department of Hydrobiology, Polish Academy of Sciences, PL-05-092 Lomianki, Poland \\ ${ }^{\mathrm{h}}$ Laboratory of Geology, EPF Lausanne, CH-1015 Lausanne, Switzerland \\ Received 19 June 2001; revised 20 February 2002; accepted 3 May 2002
}

\begin{abstract}
Soil saturation is known to be of crucial importance to denitrification and other nitrogen cycling processes within the riparian zone. Since denitrification potential generally increases towards the soil surface, water table elevation can control the degree to which nitrate reduction is optimised. Given their topographic location and sedimentary structure, most floodplains are characterised by high water tables. However, detailed field data on water table levels, hydraulic gradients and flow patterns within the riparian zone are generally lacking. This paper presents data collected as part of a pan-European study of nitrate buffer zones, the Nitrogen Control by Landscape Structures in Agricultural Environments project (NICOLAS). An identical experimental design was employed at each site, allowing riparian zone hydrology and nitrogen cycling processes to be explored across a wide range of temperate climates; only the hydrological data are discussed here. A grid of dipwells at 10-metre spacing was installed at each site and manual measurements made at least once a month for a minimum of one year. In addition, at least one dipwell in each grid was monitored continuously using a data logger. All the riparian zones studied displayed a clear annual cycle of water table elevation, although other factors seemed equally important in influencing the range of variation. Where the riparian zone was flat, the water level in the adjoining river or lake proved more significant in controlling water table levels within the riparian zone than was originally anticipated. (C) 2002 Elsevier Science B.V. All rights reserved.
\end{abstract}

Keywords: Water table; Floodplain; Riparian zone; Buffer zone; Nitrate

\section{Introduction}

\footnotetext{
* Corresponding author. Fax: +44-191-374-7472.

E-mail address: t.p.burt@durham.ac.uk (T.P. Burt).

1 Also at: NIWA, Hamilton, New Zealand.
}

The riparian zone sensu stricto includes only vegetation along the bed and banks of the river channel (Tansley, 1911). However, this meaning has subsequently been extended to include a wider strip of 
land alongside the channel (Malanson, 1993, p. 9). Given this extended definition, the floodplain and the riparian zone are now often taken to be one and the same thing. Riparian zones are ecological boundaries, or ecotones, which physically separate terrestrial and aquatic ecosystems. Riparian ecotones are important regulators of the movement of material through the catchment system, and because of this, their ecological significance and management potential has become a subject of great interest (Naiman and Décamps, 1990). Extensive research has focussed on the use of riparian zones as an effective means of preventing diffuse pollution from agricultural land reaching the river channel (Peterjohn and Correll, 1984; Burt and Haycock, 1996; Haycock et al., 1997).

Given their topographic location and sedimentary structure, most floodplains are characterised by high water tables. Even above the water table, the soil is likely to remain close to saturation given the upward extension of the capillary fringe (Gillham, 1984). Burt and Haycock (1996) and Burt (1997) have described the water balance of a floodplain in significant detail. High water levels are maintained by a variety of processes: inflow from adjacent hillslopes, upwelling groundwater, inflow from the river channel via bank seepage or overbank inundation, and rainfall. Very low gradients across the floodplain, often in conjunction with fine-grained alluvium, help to sustain waterlogged conditions, especially where the floodplain is wide. Nevertheless, in summer, the water table may well fall significantly as inflows from nearby slopes diminish. Continued evaporation will lower the water table even further. Under such conditions, the normal hydraulic gradient may even reverse, with discharge from the river to the floodplain, especially during flood events (Haycock and Burt, 1993; Bates et al., 2000; Burt et al., 2002). In autumn, water table levels within the floodplain and on adjacent slopes rise again, and flow towards the river is re-established. In the lower reaches of the basin, the river is more likely to burst its banks and the floodplain can remain inundated for long periods. At the very least therefore, floodplains form seasonal wetlands; in many cases waterlogged conditions exist throughout the year (Burt, 1995).

Most process studies of floodplain hydrology have focussed on bank storage, emphasising the attenuation of the flood wave, rather than the dynamics of the water table. Since the hydrological condition of the floodplain can significantly influence the passage of the flood wave and the pattern of floodplain inundation, there have been several studies of floodplain inundation and recharge of alluvial aquifers by surface water (see review in Winter (1995)). Bates et al. (2000) and Burt et al. (2002) have studied the relative contribution of bank storage and slope discharge in controlling water table levels in the floodplain of the River Severn in central England. Autumn floods generate flows from the channel into the floodplain, producing a 'reverse' ridge of groundwater that migrates across the floodplain towards the slope. (This should not to be confused with the groundwater ridge that may develop within the floodplain during storm events due to the effect of the capillary fringe, as mentioned below). Later in the season, when soils have recharged, hillslope discharge becomes much more significant, especially during the recession period after the flood peak has passed. Many authors have described how discharge from the floodplain can maintain baseflow in the river (e.g. Kondolf et al., 1987). Floodplains might also be a source of storm runoff, particularly overland flow from areas where the ground is fully saturated; any increase in subsurface discharge as a result of rising water tables would be further enhanced via the hypothesised groundwater ridging mechanism (Gillham, 1984; Buttle and Sami, 1992). However, only a limited number of studies have identified the hydrological pathways operating within floodplains or riparian wetlands (Hill, 1990; Waddington et al., 1993; Squillace, 1996; Burt, 1997), or have provided details of water table fluctuations within floodplains (Nortcliff and Thornes, 1984; Haycock and Burt, 1993; Mertes, 1997; Burt et al., 1999). The importance of hydrology in controlling buffer zone functions in the riparian zone is reviewed inter alia in Haycock et al. (1997), Hill (1997), and Cirmo and McDonnell (1997).

All the studies reported here are for undrained riparian zones. Artificial drainage of the floodplain, whether by surface ditches or underground pipes, lowers water tables significantly, and allow extended use of the flat and often very fertile floodplain land. The impact of land drainage on buffer zone function is likely to depend on the type of pollutant being considered: dry floodplain soils encourage infiltration 


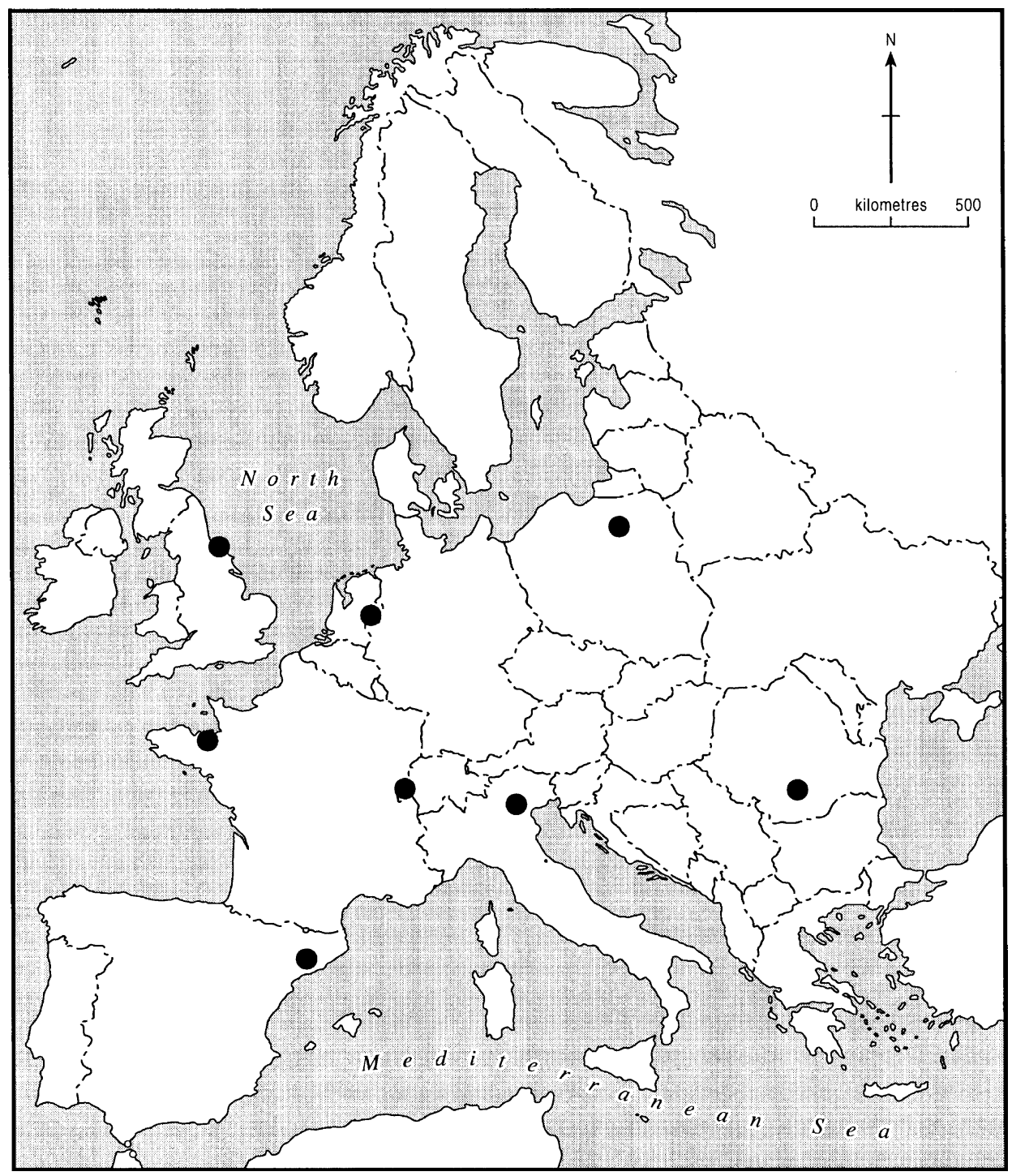

Fig. 1. Location of the NICOLAS study sites.

of sediment-laden overland flow (Dillaha and Inamdar, 1997), but unsaturated, aerated conditions may well prevent anaerobic processes like denitrification from operating effectively (Knowles, 2000). The drainage system provides a conduit for hillslope water to move rapidly across the floodplain, minimising the potential impact of any buffer zone processes. Moreover, the riparian zone itself also becomes a source of pollution, the more so given its proximity to the channel. Thus, in relation to denitrification, riparian wetlands in their natural state provide a barrier between slope and river, whereas land drainage strongly couples slope to river bypassing buffer zone functions of the riparian zone.

The overall aim of the Nitrogen Control by Landscape Structures in Agricultural Environments (NICOLAS) project was to evaluate the natural ability of morphologically similar riparian structures experiencing different climatic regimes to buffer the movement of diffuse nitrate pollution from farmland to surface water. There were four 


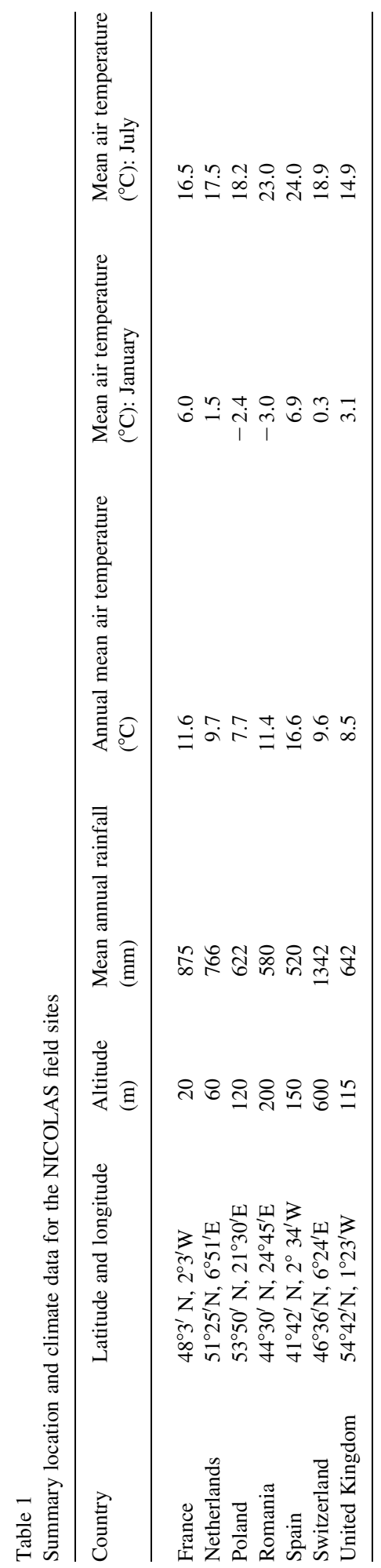

objectives within the NICOLAS programme: to quantify the nitrogen cycle within each riparian zone studied; to use a riparian ecosystem management model (REMM, Lowrance et al., 2000) to predict the nitrogen fluxes through buffer zones under a wide range of farming and climatic conditions; to identify the impact of establishing riparian buffer zones on farm operations; and, to compare the effectiveness of riparian buffer zones with other potential buffering structures (e.g. ponds, hedgerows). Given that the first objective was to evaluate nitrogen retention and transformation processes, a crucial task at each study site was to assess the significance of various nitrogen uptake mechanisms within the riparian zone under varying hydrological regimes. The nitrogen buffering capacity of riparian zones is known to be controlled by two main processes, microbial denitrification and microbial and plant uptake (Haycock and Pinay, 1993). Denitrification is thought to be more effective during high-water periods and involves the complete loss of nitrogen in gaseous form $\left(\mathrm{N}_{2}\right.$ or $\left.\mathrm{N}_{2} \mathrm{O}\right)$, while uptake is only a temporary retention process, being more efficient during the growing season. It was therefore important, as part of the NICOLAS programme, to characterise the water table response at each site and relate this to the pattern of nitrogen cycling. In relation to this hydrological work, initial hypotheses were established as given below:

- In headwater tributaries, where floodplains are relatively narrow, soil moisture conditions within the floodplain will be predominantly controlled by runoff from the upslope catchment, not by fluxes from the river to the floodplain.

- Given the climatic regime within Europe, all floodplains studied will have a clear annual cycle of water table fluctuation, but the strongest seasonal regime will be seen in regions where large soil moisture deficits develop in summer, i.e. Mediterranean and continental climates.

- Other things being equal, high water tables will be sustained for the longest time in floodplains with soil/alluvium of low hydraulic conductivity. 


\section{Experimental methods and study locations}

\subsection{Field sites}

The location of the NICOLAS study sites within Europe are shown in Fig. 1; summary, location and climate data are provided in Table 1. Full site descriptions can be found in Pinay and Burt (2001).

France. The French study area is located along a fourth order stream (Petite Hermitage) in north-west France. The catchment drained by the riparian zone is mainly agricultural with crops (maize and wheat) and grass for grazing cattle. Fertiliser application rates are high, about $200 \mathrm{~kg} \mathrm{~N} \mathrm{ha}^{-1} \mathrm{yr}^{-1}$, which has resulted in elevated groundwater nitrate concentrations ranging from 10 to $20 \mathrm{mg} \mathrm{N}^{-1}$. The riparian zone comprises a wetland about $80 \mathrm{~m}$ wide from the bank to the stream. An old channel, roughly parallel to the stream and $30 \mathrm{~m}$ from the hillslope, flows in winter but dries up during summer. (A new channel was dug at some stage along the southern border of the wetland, but the original channel nearer to the hillslope continues to strongly influence the riparian zone hydrology.) The soil profile within the wetland consists of an organic upper horizon, a clay-silt horizon with ferrous oxidation spots and a deeper inorganic horizon of fine clay resulting from weathering of the schist substrate. Along the valley floor, three sites were selected: a woodland, a meadow and a shrub zone. Each grid of dipwells was located between the hillslope and the old channel.

Netherlands. The Dutch site is located in the east of the Netherlands near the German border. Two riparian buffer zones, both approximately $20 \mathrm{~m}$ wide, were selected along two comparable first order streams: a riparian woodland (mainly alder) on the Hazelbeek stream and a grassland zone on the Ribbert stream. A glacial moraine with gentle slopes facing west and east underlies the whole area. These slopes consist mostly of impermeable glacial till covered by a layer of aeolian sand up to $40 \mathrm{~m}$ thick at the centre of the moraine. Both streams are perennial, having their source areas within the sand aquifer close to the top of the moraine. On the higher ground, fertile agricultural ('eerdgrond') soils with a layer rich in organic matter up to $1 \mathrm{~m}$ deep have been created; these are now intensively farmed for maize. In the valleys, the soils have a peaty topsoil, $10-30 \mathrm{~cm}$ deep, developed on a sandy substrate; at greater depth, stones and clays can be found. Valley soils have clear redoximorphic features and are characterised by high groundwater levels ( ) throughout the year. In the adjoining field, water table depth varies from 40 to $>120 \mathrm{~cm}$.

Poland. Two study sites were selected near Mikołjki in the Mazurian Lakeland of NE Poland, an area underlain by loam and sandy-loam moraine deposits. The riverside site comprises two zones: a zone of coppice woodland 4-6 m wide, them a 6-8 m herbaceous strip. Upslope is a meadow, which is fertilised and mowed, and occasionally grazed. The upland slope varies between 3 and $7^{\circ}$ and is about $25 \mathrm{~m}$ long. There are silty sands on the slope with alluvial deposits intermixed with organic matter in the riparian zone. The lakeside riparian zone is about $28 \mathrm{~m}$ wide, and is dominated by alder. It adjoins a steep $\left(15-18^{\circ}\right)$ slope farmed for rye, wheat and maize, about $100 \mathrm{~m}$ long.

Romania. The study area is located in the southern part of Romania, $90 \mathrm{~km}$ WNW from Bucharest, on the upper part of the Glavacioc stream, a second order stream of the Arges River, tributary of the Danube. Here the river is surrounded by a large reed wetland (70-100 m wide). The two study sites, a meadow and a forest both about $12 \mathrm{~m}$ wide, are located on the inland edge of the wetland. Slope gradient is $2^{\circ}$ for the meadow and $6^{\circ}$ for the forest. Soils are formed from loess deposits of low permeability. Soils are gleyic chromic luvisols with a Bt horizon and a reduced gleyic horizon below. The adjacent agricultural land is used for winter wheat, sunflowers, oats, barley and maize production. No fertiliser has been applied to these fields for at least a decade.

Spain. The Spanish study site is located in a forested catchment near Barcelona. It comprises a woodland riparian zone $8 \mathrm{~m}$ wide located between a field and the Fuisosos stream. The bedrock is granitic; above the bedrock there is a layer of weathered rock 2-6 $\mathrm{m}$ deep, and above that, sandy soil 1-2 m deep. Slope drainage is mainly within the weathered layer; the soil is never saturated. The stream is ephemeral, drying up from July to September when the water table falls to $1 \mathrm{~m}$ below the streambed. The riparian zone has an average slope of $22 \%$ and is dominated by sycamore and alder.

Switzerland. The Swiss site is near Montricher in the Lausanne region on undulating plateau country 


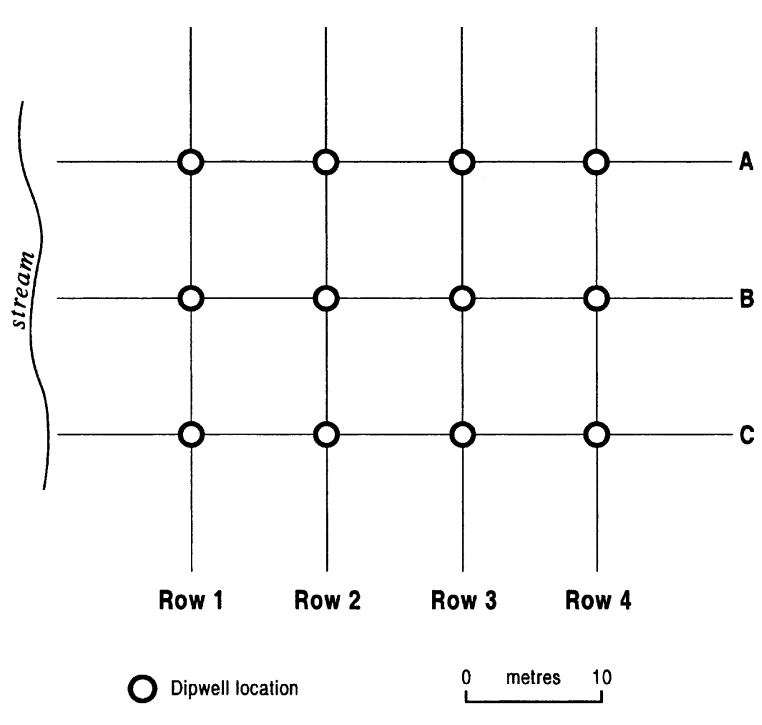

Fig. 2. Layout of the dipwell grid at each site.

south of the Jura Mountains. The site consists of a 3\% slope adjacent to a flat riparian zone. The substrate comprises fluvioglacial material, very variable in character-from sandy gravels to silty sands, overlying a compacted silty-clay till of low hydraulic conductivity. Soils form a catena, from brown soil on the upper slope, through brown redoximorphic soil on the middle and lower slopes, to peat in the riparian zone. The forested area is mainly alder but in one area, willow is equally important.

United Kingdom. The UK study area is located within the headwaters of the River Skerne, near Trimdon in County Durham, NE England. It comprises three riparian sites: a riparian woodland, a grass floodplain, and a riparian wetland. The same grass field lies upslope of all three sites; it supports intensive sheep farming with some cattle and horses, although little fertiliser is used $\left(<50 \mathrm{~kg} \mathrm{ha}^{-1}\right.$ $\left.\mathrm{N} \mathrm{yr}^{-1}\right)$. A thick, impermeable deposit $(\sim 30 \mathrm{~m})$ of glacial origin, mainly clay with some thin sand and gravel layers, underlies the area. Soils comprise an A horizon of about $20 \mathrm{~cm}$ depth above an orange-brown or bluish clay substrate. At the woodland site, a number of boreholes contained sand and gravel at depth; this layer appeared to conduct groundwater at a much higher rate than the normal clay substrate. The woodland buffer zone is about $70 \mathrm{~m}$ wide. Slope gradient is $4^{\circ}$ in both the grass field and the woodland. At the grassland site, there is a flat floodplain about
$15 \mathrm{~m}$ wide. Total slope length is about $500 \mathrm{~m}$. The forested zone comprises an even-age stand approximately 50-60 years old, dominated by sycamore, with some beech and larch.

\subsection{Mapping water table levels}

An important aim of the field experiments within the NICOLAS programme was to measure water table elevation across the riparian zone and thereby establish flow rate and direction within riparian zone sediments. Subsurface flow through the soil and deeper sediments of the riparian zone is known to be of crucial importance to denitrification and other nitrogen cycling processes (Haycock and Burt, 1993). Denitrification potential generally increases, with organic matter content, towards the soil surface (e.g. Burt et al., 1999); it follows that water table elevation will control the degree to which nitrate reduction is optimised. However, flow patterns across low-angled floodplains comprising heterogeneous sediments can be complex, so that a single transect of measurements across the riparian zone orthogonal to the river channel may well not provide an adequate picture of subsurface flow pathways. For this reason, a grid of dipwells was installed at each site following the experimental design developed by Haycock and Burt (1993) and Burt et al. (1999). Each grid comprised a 4-6 rows of dipwells parallel to the river, with at least three in each row, at $10 \mathrm{~m}$ spacing. The nearest row to the river was designated Row 1, etc. (Fig. 2); dipwells along a given row are indicated by letter. Additional dipwells were installed where needed to provide more detail (e.g. in an old oxbow channel). Each dipwell consisted of an open hole drilled down into the saturated zone, lined using a plastic pipe $25-50 \mathrm{~mm}$ diameter, perforated $(5 \mathrm{~mm}$ holes at $20 \mathrm{~mm}$ intervals) along its length and sealed at the bottom to prevent ingress of sediment. Where a layer of low permeability was known to exist at a shallow depth $(<5 \mathrm{~m})$, the hole was extended down into that layer. In uniform, deep sediments, the aim was to make the holes deep enough to intercept the water table throughout the year. Holes were drilled by hand or using a power auger. Where the tube was 


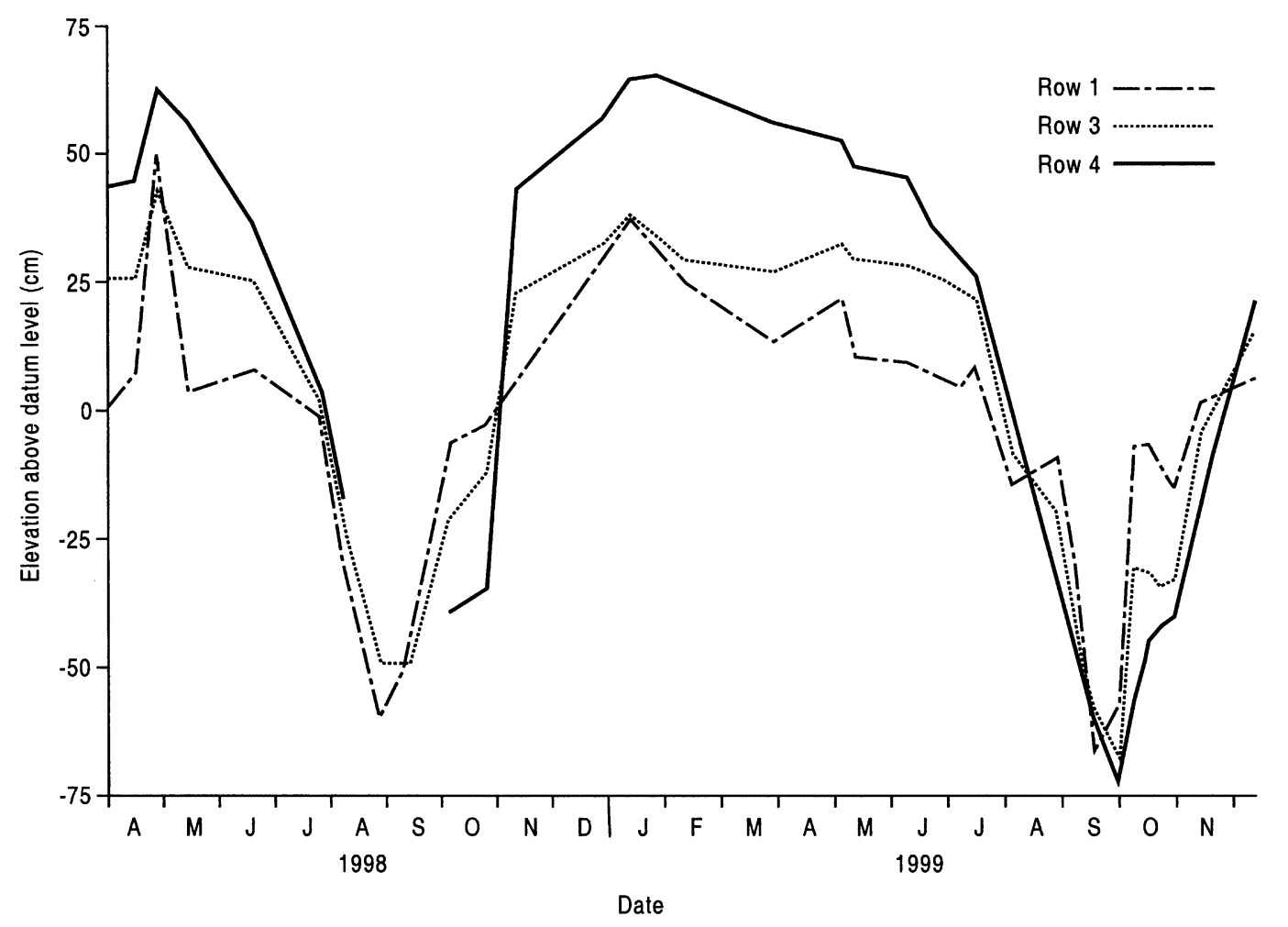

Fig. 3. Average water table elevations by row at the French grass site, April 1998-December 1999. Data for row 2 have been omitted since they are very similar to row 1 .

significantly smaller than the auger hole, soil slurry was used to fill the space, with a seal of bentonite clay to prevent rainwater from seeping down the hole. The top of the tube was capped, or covered by a heavy metal plate. Water table elevation was measured at every dipwell at least monthly using a suitable probe. At least one dipwell in each grid was monitored continuously using a data logger. Ring infiltrometers were used to measure infiltration capacity, and either auger hole methods or pumping tests were used to measure the saturated hydraulic conductivity of the soil, depending on the depth of the water table.

At each NICOLAS field site, the grid of dipwells was located to include both an area of riparian woodland and, upslope, an area of adjoining farmland. In addition, most NICOLAS field sites included variants of this standard experimental design, for example, a riparian zone with no strip of woodland alongside the stream.

\section{Results}

\subsection{Seasonal variation}

Irrespective of location within Europe and the specific characteristics of winter and summer climates (Table 1), a strong seasonal cycle of water table fluctuation is evident. It might be expected that continental (e.g. Poland) or Mediterranean (e.g. Spain) sites would register a larger seasonal amplitude than cool temperate sites in north-west Europe (e.g. UK), but in fact the seasonal cycle is clear at all sites. Fig. 3 shows the pattern of water table fluctuation at the French grassland site, averaged by row, for the period April 1998-December 1999. These results demonstrate a number of features evident at all the NICOLAS sites, of which a clear seasonal variation is the most notable. At a particular site, the amplitude of the cycle is greater upslope, away from the river or lake; thus at the French site, row 4 (hillslope) shows the greatest variation, from $+65.6 \mathrm{~cm}$ above datum on 


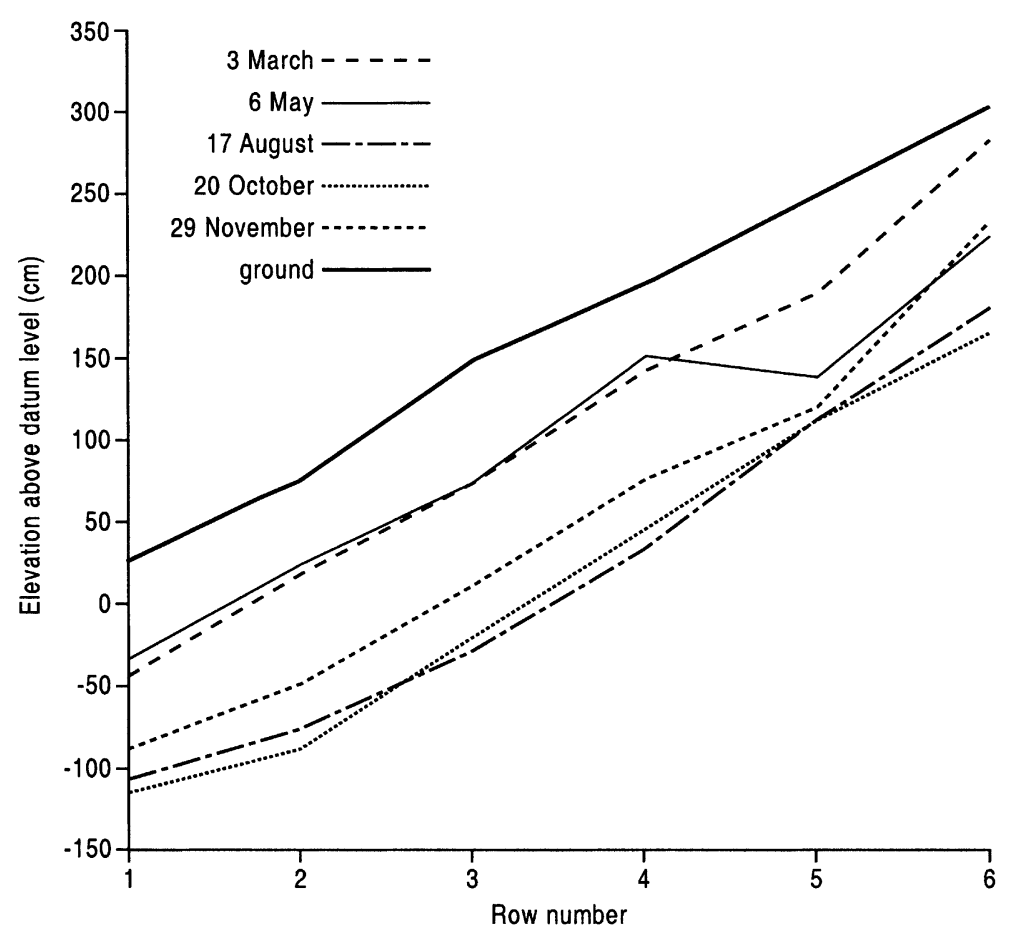

Fig. 4. Water table profiles, averaged by row, at the UK woodland site, March-November 1999.

18-1-99 to $-71.7 \mathrm{~cm}$ on $21-9-99$. Nevertheless, though more muted, the range for row 1 (floodplain, next to the stream) is still clear, from +31.3 to -56.1 on the same dates. Row 3, at the inland boundary of the riparian zone, shows an intermediate response. One implication of this pattern is that the effective boundary between hillslope and riparian zone (defined in terms of the water table being at or close to the soil surface) shifts downslope, i.e. nearer the stream, during the summer. Denitrification is most efficient when the water table is high and the organic surface horizon is saturated (Burt et al., 1999). The water table may be too deep on the hillslope in summer for denitrification to operate optimally, although some activity may still occur at depth.

\subsection{Water table fluctuations on riparian hillslopes}

At most NICOLAS sites, there is a zone of flat ground adjacent to the river, but in some cases (UK woodland, Romania) the land slopes right down to the water's edge. Where the riparian zone is flat, the water level in the river can act as a fixed point around which the riparian water table fluctuates, higher than the river in winter but sometimes lower in summer. However, where a slope directly borders the river, the river cannot significantly influence water table fluctuations in the riparian zone since there will rarely be a hydraulic gradient away from the river towards the land. In Fig. 4, average water table elevation by row is shown for the UK riparian woodland; the boundary with the grass field is at row 4 . The pattern is essentially one of parallel response, with all rows showing much the same response to seasonal variations in inflow to the riparian zone. The slope is sufficient $\left(4^{\circ}\right)$ that fluctuations in river stage are not influential, except presumably very close to the river (i.e. downslope of row 1); in addition the channel is incised, further limiting the river's influence. Fig. 5 maps water table elevation across the UK riparian woodland on five occasions through the study period; ground surface elevation is also shown. The uniform pattern of water table fluctuation across the site translates into a sideways movement of water table contours on the various maps. Thus, moving from winter to summer, the contours are seen to migrate in 

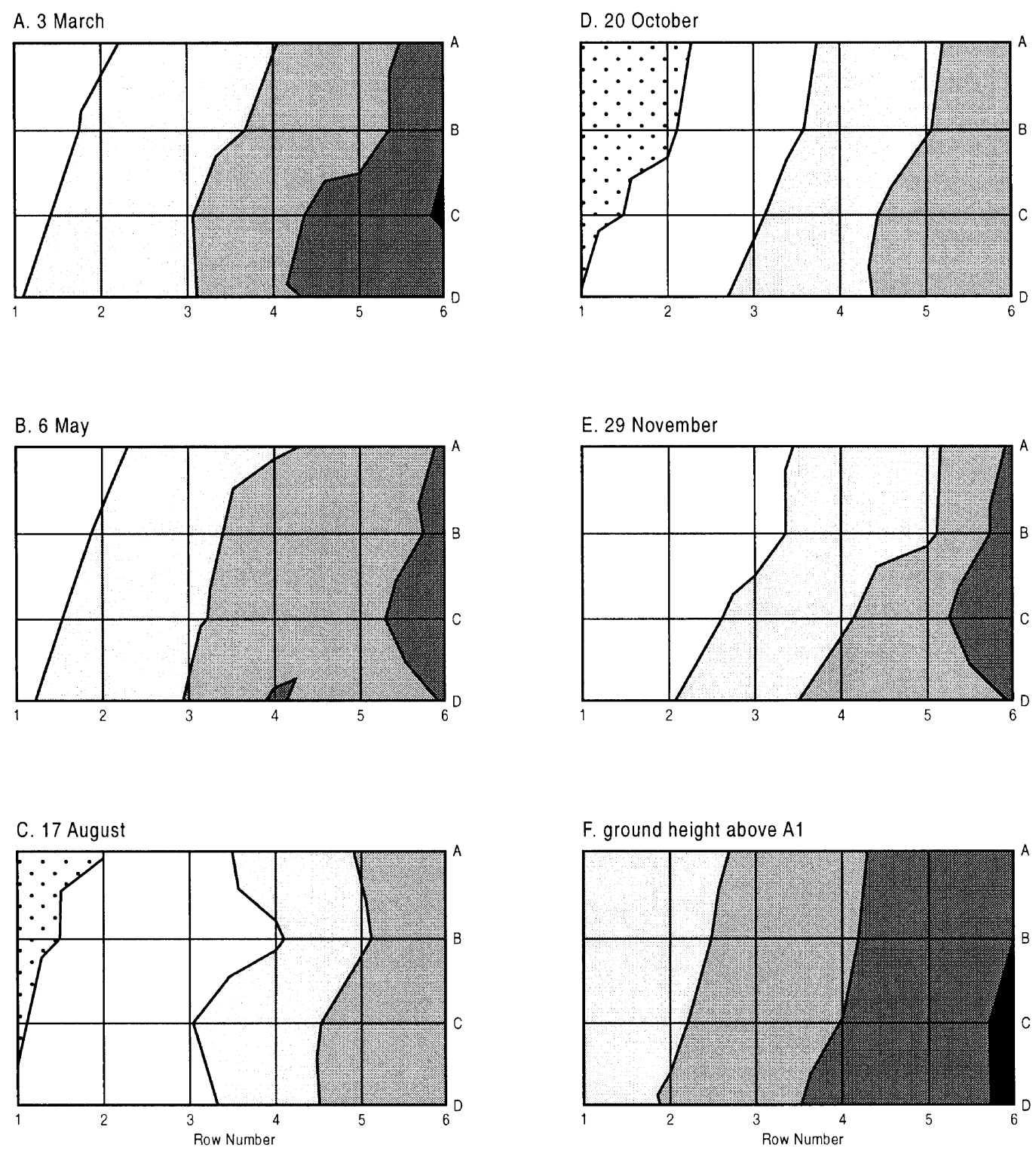

F. ground height above $A 1$
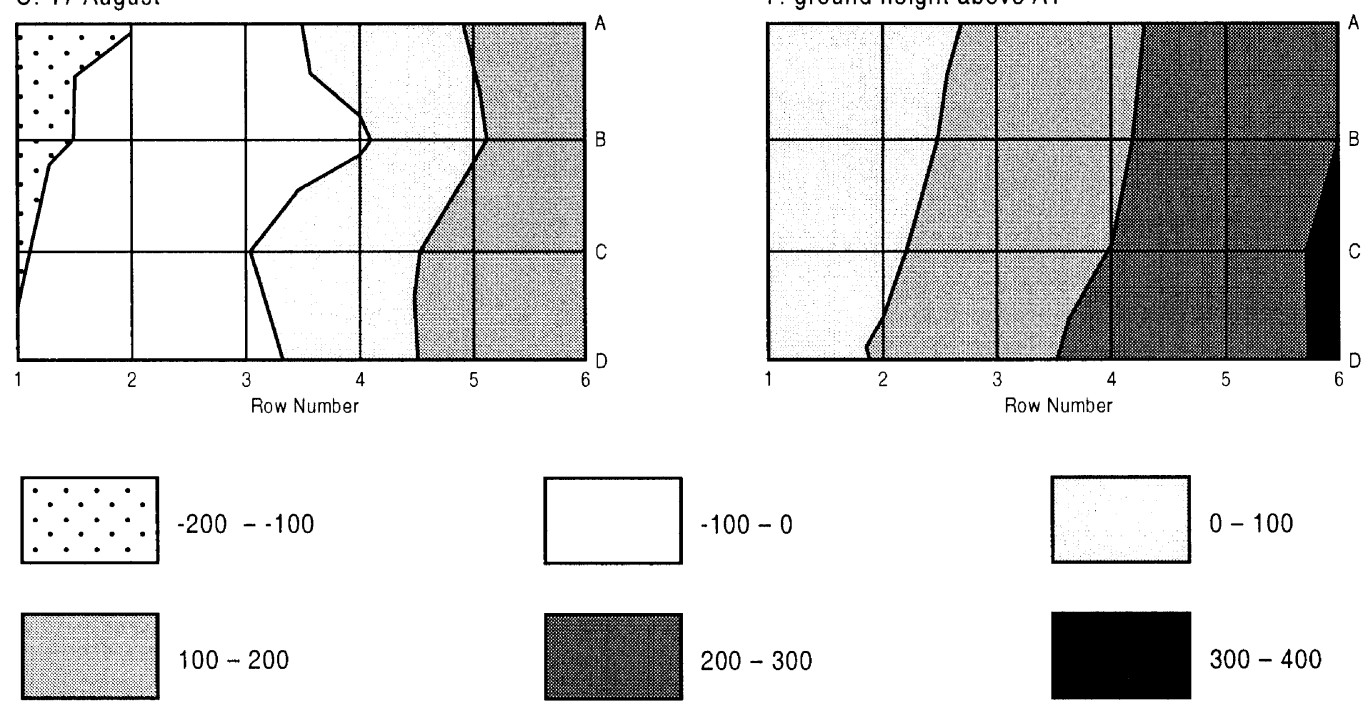

$100-0$

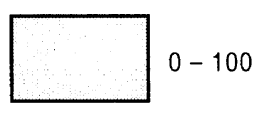

$200-300$

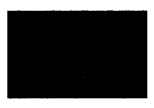

$300-400$

Fig. 5. Maps of water table elevation at the UK woodland site for selected dates in 1999; the ground surface elevation for the site is also shown. 


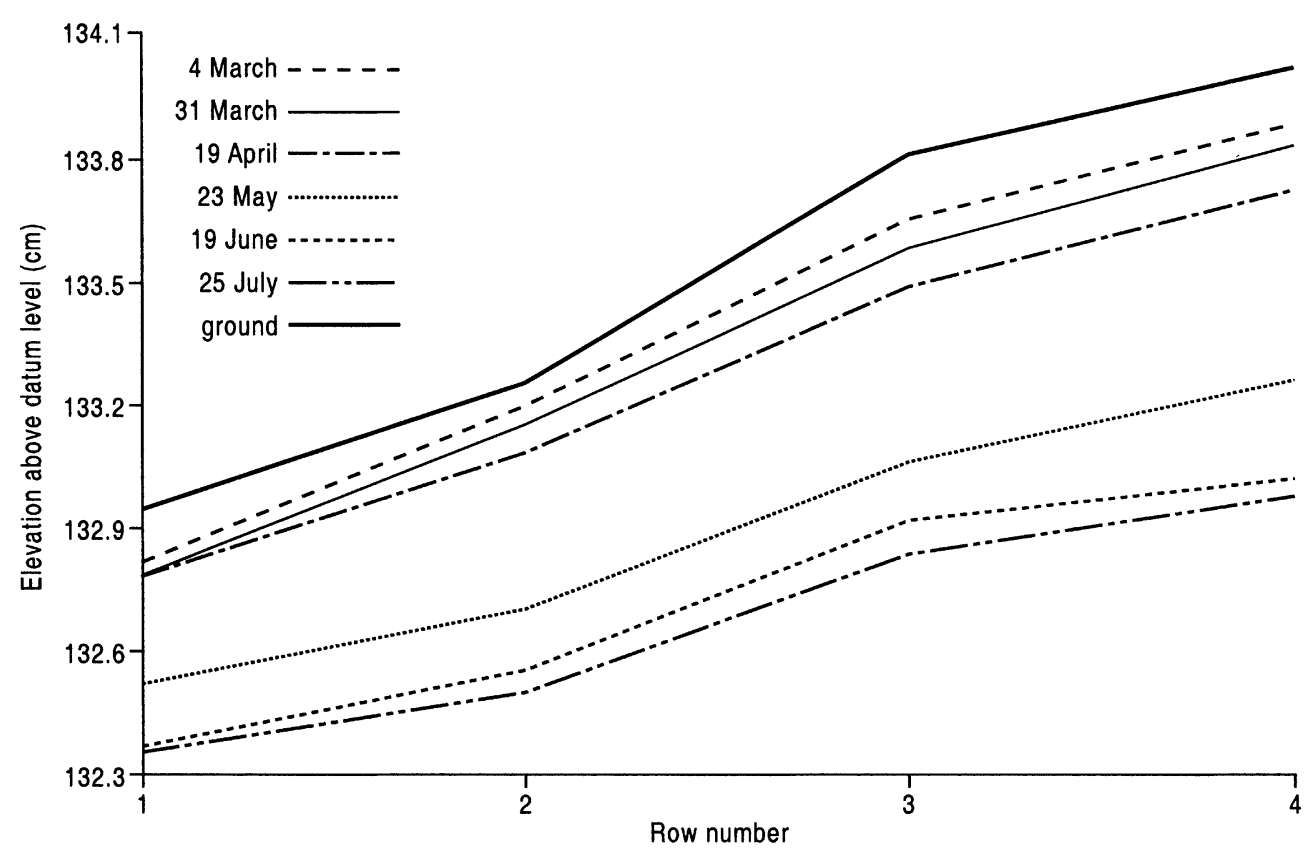

Fig. 6. Water table profiles, averaged by row, for the Romanian forest site, spring and summer 2000.

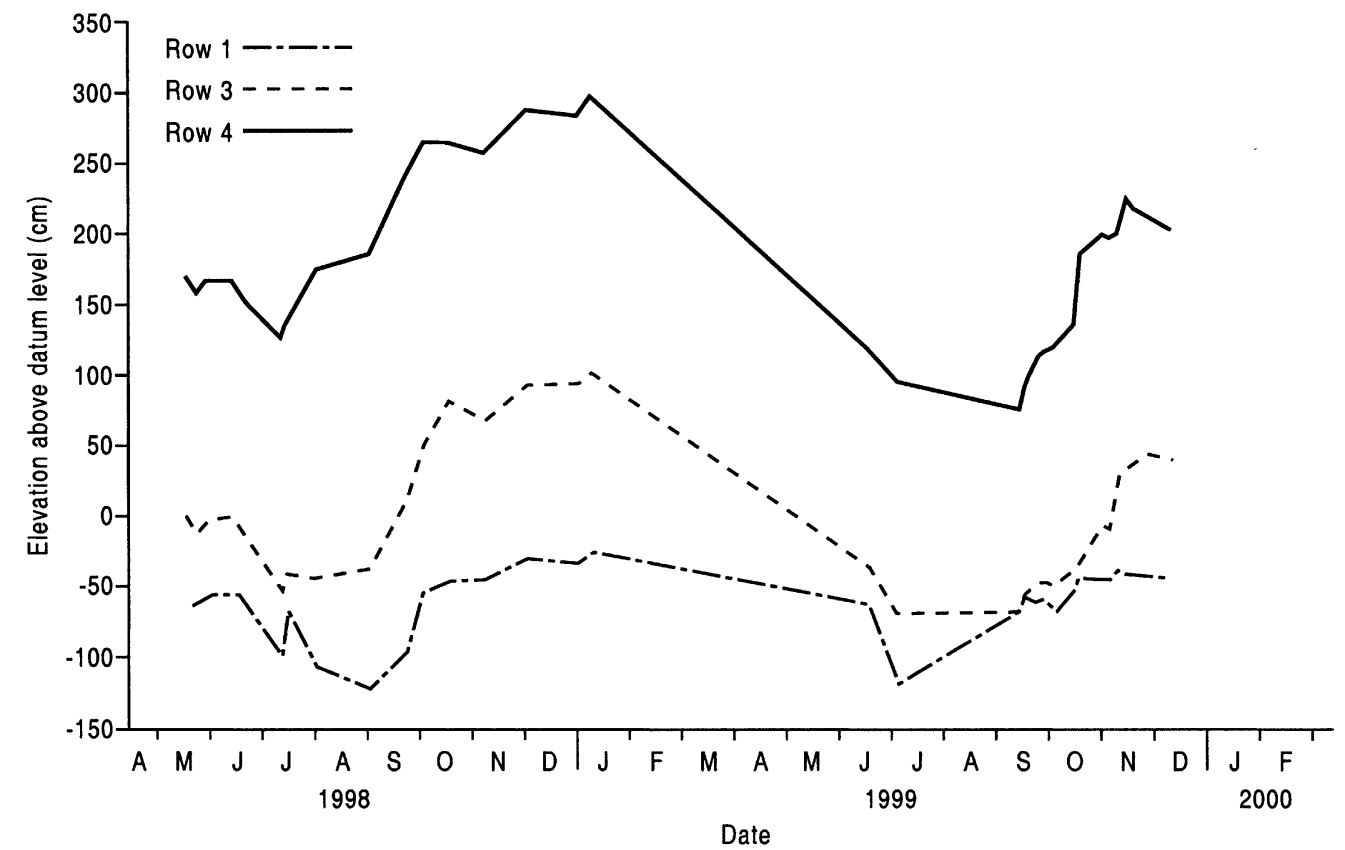

Fig. 7. Average water table elevations by row at the Spanish site, May 1998-December 1999. Data for row 2 have been omitted since they are very similar to row 1 . 


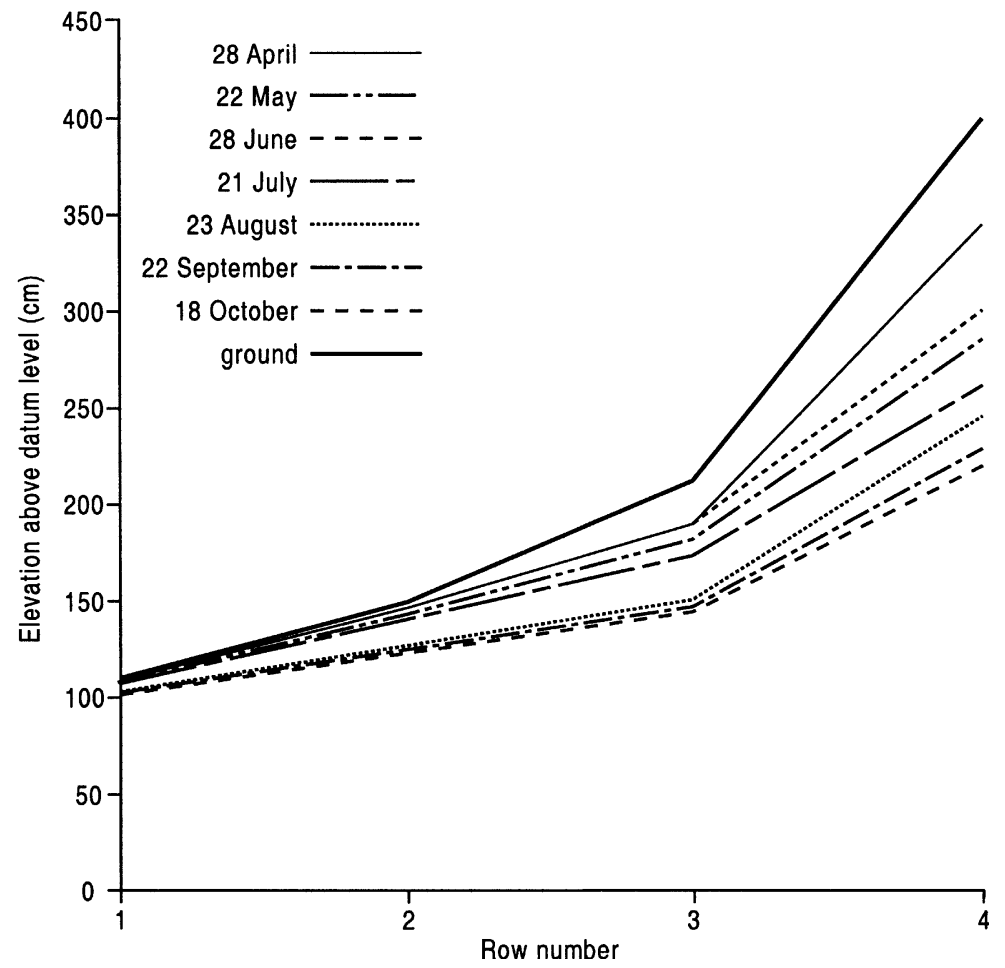

Fig. 8. Water table profiles, averaged by row, at the Dutch woodland site.

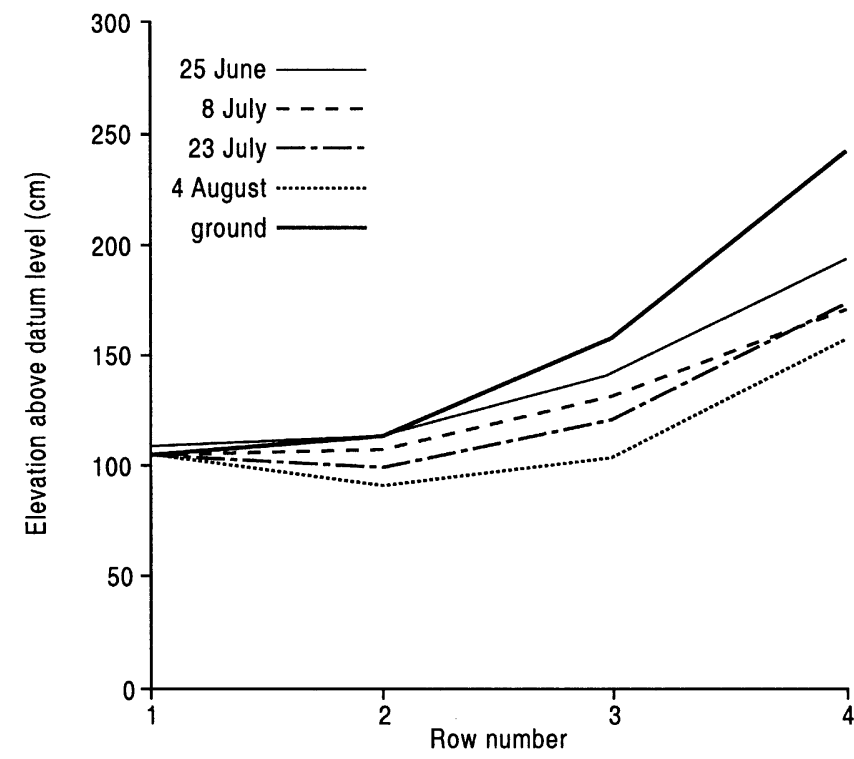

Fig. 9. Water table profiles, averaged by row, at the Polish lakeside site. 


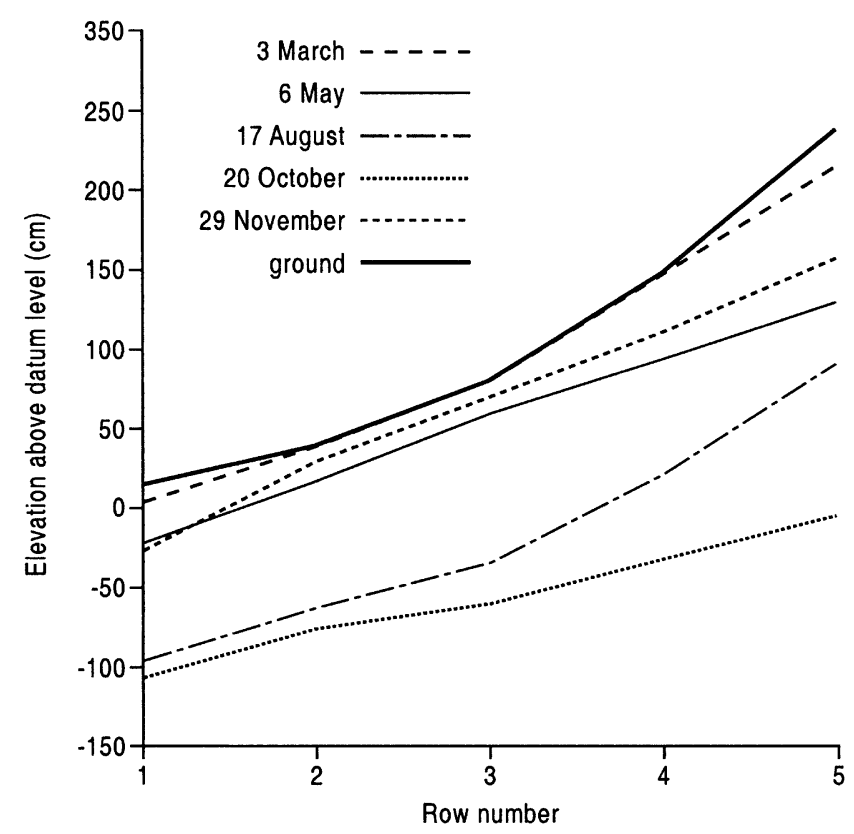

Fig. 10. Water table profiles, averaged by row, at the UK grassland site, March-November 1999.

parallel in an upslope direction, with a reverse pattern in autumn.

Fig. 6 shows selected water table profiles during spring and summer 2000 for the Romanian forest site, which lies between a field (upslope) and a wetland (downslope). The ground slope is similar to the UK site and again the water table response is parallel. Like the UK woodland site, the water table at the lower end of the slope varies in much the same way as on the rest of the slope and is not fixed in position by a constantlevel water table within the wetland. The response again suggests one largely controlled by upslope discharge; the water table is not significantly influenced by either influent seepage from the river channel or conditions within the riparian wetland itself. Most importantly, because of the influence of the slope, the water table does not remain close to the soil surface for very long at either site, thus limiting the potential for denitrification to take place. A similar 'parallel' response has also been observed at the Swiss site.

\subsection{Riparian zones influenced both by river (or lake) and slope}

Fig. 7 shows water table elevations averaged by row for the Spanish site during the study period. The pattern is similar to that for the French site (Fig. 3) in that the hillslope shows the largest amplitude whereas the response is much more subdued close to the stream. The range at row 4 is almost $2 \mathrm{~m}$ whereas at row 2 it is just less than $1 \mathrm{~m}$. The large range of response on the hillslope suggests a pattern of winter recharge controlled by conditions upslope. In contrast, the constrained response near the stream suggests that both hillslope and river exert control of riparian water tables: the water table cannot fall very low in summer because of the influence of river stage (even after the channel dries up, since the water table remains within $1 \mathrm{~m}$ of the channel bed). In winter the higher levels may reflect both higher river stage and larger amounts of inflow from upslope.

Where the riparian water table is controlled in part by water level in the adjacent river or lake, a 'hinged' pattern of response is evident. Figs. 8 and 9 show the seasonal pattern of response at the Dutch woodland and Polish lakeside sites, respectively. The Dutch site (Fig. 8) indicates a wide range of response on the slope, but a much lower range of fluctuation on the floodplain. Given a steady flow in the groundwaterfed stream throughout the year and a shallow river channel, the river stage remains fairly constant 


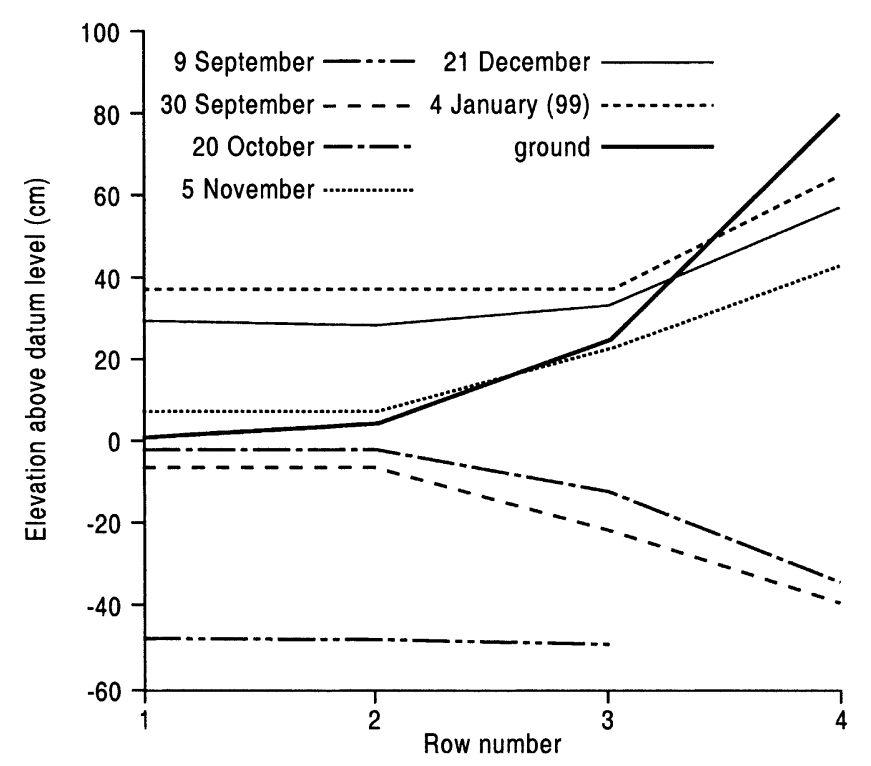

Fig. 11. Water table profiles, averaged by row, for the French grass site, September 1998-January 1999.

throughout the year. As a result, the water table in the floodplain remains close to the ground surface. Groundwater seepage from the local aquifer also helps maintain the floodplain water table level. Thus, in the Dutch case, inflows from both river and slope combine to sustain high water levels within the floodplain throughout the year. A very similar pattern is evident at the Polish site (Fig. 9), although in this case it is notable that the water table slopes away from the lake in mid-summer. This suggests that the slope discharge has fallen to insignificant levels, probably because of high evaporation losses, and that inflow from the lake alone is now sustaining water tables in the riparian zone. (Given the broadened usage of the word, it seems acceptable to describe the lake shore as 'riparian' too.) The flow of water from lake to riparian zone is a similar process to the bank storage effect seen during floods (Burt et al., 2002) but, of course, at the Polish lake site the hydraulic gradient from lake to riparian zone is sustained, not ephemeral. In flood events, recharge of the floodplain is short-lived and once river stage falls, the normal pattern of flow from floodplain to river is soon re-established. In the Polish example, the process of riparian zone recharge is evidently sustained over a long period of time, indeed until the riparian and slope soils rewet during the autumn, at which time the flow direction reverses and the riparian zone once more drains towards the lake.
The effect is similar to that seen at the French site during the summer months (see below).

Fig. 10 shows results for the UK grassland plot. Here there is a narrow zone of flat land about $15 \mathrm{~m}$ wide, backed by a $5^{\circ}$ slope; however, the river level is normally about $1 \mathrm{~m}$ below the floodplain surface. The results again show an essentially parallel response, although if one compares the profiles for 3 March and 6 May, there is some evidence of a steeper water table on the slope in winter. The topography of the site and the low hydraulic conductivity of the soil means that it soon becomes saturated in the autumn, and the water table then remains close to the surface throughout the winter; only upslope does the water table remain deeper below the surface. There is no evidence here of significant bank recharge, so slope discharge (plus rainfall directly on to the floodplain) must be responsible for maintaining soil saturation within the riparian zone. At the UK wetland site (data not presented here), there is again no evidence of flow from river to hillslope; the river level is usually a metre or more below the wetland, which is dammed behind an artificial levée. Here an exaggerated hinged water table response is seen. Again, it seems that hillslope runoff, plus rainfall, is sufficient to sustain soil saturation within the wetland throughout the summer so that the water table falls by only a few centimetres at most. The wetland is some $50 \mathrm{~m}$ wide; 
A. 30 September

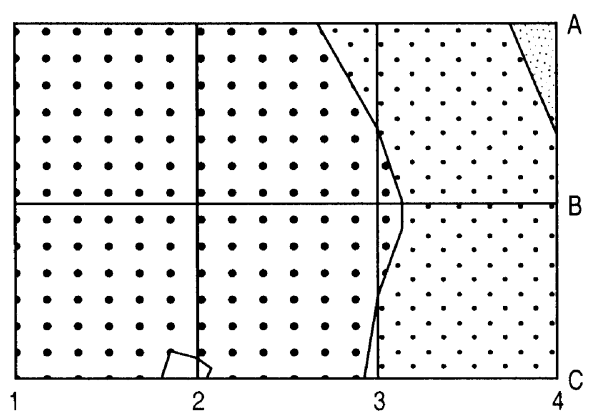

B. 20 October

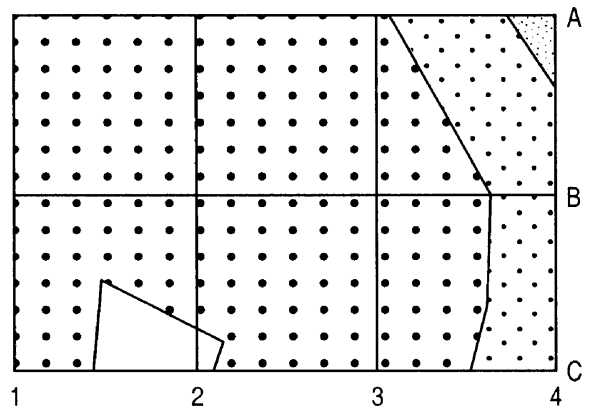

C. 05 November
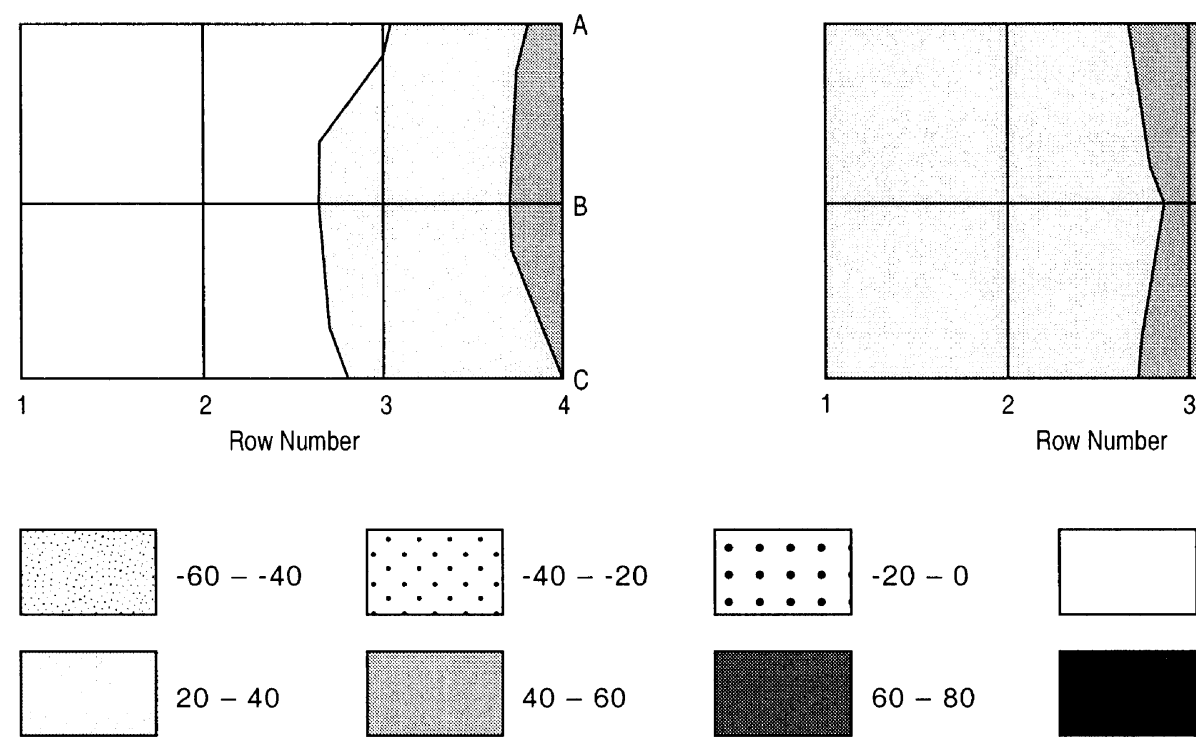

E. 4 January (99)

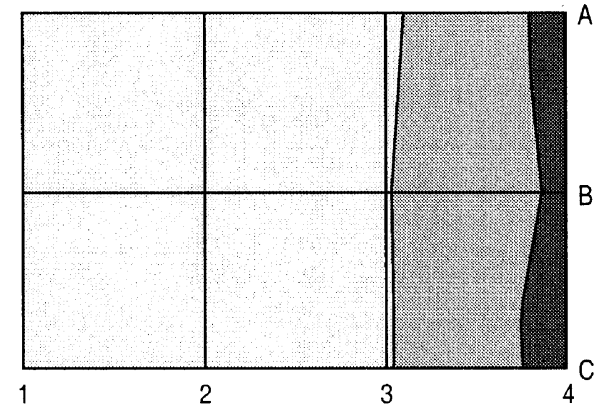

F. ground height above A1

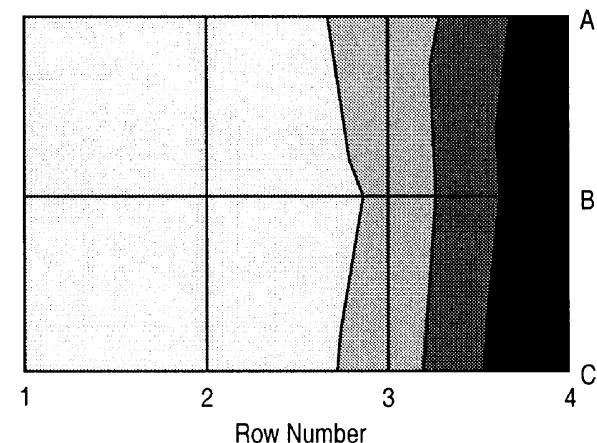

$0-20$

$80-100$

Fig. 12. Maps of water table elevation at the French grass site for selected dates in the autumn and winter of 1998-1999; the ground surface elevation for the site is also shown. 
the combination of width, low hydraulic gradient and low soil hydraulic conductivity explains why this area is so poorly drained. On the hillslope the range of water table response is much greater, increasing upslope, so that water table on the slope is seen to fluctuate around the fixed level of the wetland. This is a similar response to several of the other NICOLAS sites therefore.

Fig. 11 shows average water table elevation, averaged by row, for the French grass site; again, a hinged response is seen. Water table elevation varies seasonally by about one metre on the floodplain, falling to a minimum in late summer (Fig. 3). Fig. 11 shows that recharge of floodplain soils in early autumn occurs by seepage through the channel bank. A hydraulic gradient is established towards the slope, where the water table remains very low, even by 20 October. Significant rainfall at the end of October restores soil saturation on the hillslope and reverses the hydraulic gradient by 5 November. Thereafter, the floodplain is inundated and the water table rises close to the ground surface on the slope. The presence of a reverse groundwater ridge (similar to that described by Bates et al. (2000) and Burt et al. (2002)) within the floodplain is clearly evident on 30 September and 20 October. By 5 November, the turnaround of hydraulic gradient is obvious, and after that the water table gradient on the slope becomes considerably steeper as soils on the slope continue to wet up. Fig. 12 shows maps of water table elevation at the French grass site (relative to ground level at dipwell A1) for five occasions during the autumn and winter of 1998/ 1999. A contour map of the ground surface is also included. The reversal of hydraulic gradient between 20 October and 5 November can clearly be seen. On the floodplain, the rise in water table is modest, only about $8 \mathrm{~cm}$ on average for rows 1 and 2, moving the water table from just below the ground surface to just above. It is on the slope that the change is much more striking with an average rise in water table of $35 \mathrm{~cm}$ in row 3 and $77 \mathrm{~cm}$ in row 4. Thereafter, a 'normal' water table slope was maintained on the slope throughout the winter and through to the following summer. Indeed it was still clearly evident as late as 7 July 1999-data not shown on Fig. 12-and the summer reversal in hydraulic gradient was not seen again until 19 August (1999). Topographically therefore, the annual range in water table fluctuation is much greater on the slope than on the floodplain, where seepage from the channel maintains the water table during the late summer, by which time there is a large soil moisture deficit on the slope.

\section{Discussion}

In locations where sloping land borders a river, the behaviour of the water table within the riparian zone is largely determined by upslope conditions and the influence of the adjacent river or lake on riparian soil hydrology will be limited. On such slopes, the water table tends to vary uniformly up the slope, remaining more or less parallel to the ground surface throughout the year, regardless of depth. This pattern of hillslope hydrology is well known in the literature, having been described on numerous occasions (e.g. Weyman, 1973; Anderson and Burt, 1978; Burt and Butcher, 1985). Buffer zone functions such as denitrification are most effective where there is sustained soil saturation. It does not necessarily follow, however, that this will be in locations where the conditions for subsurface flow are optimal: i.e. steep slopes with deep, permeable soils overlying impermeable bedrock (Anderson and Burt, 1990). Results at some of the NICOLAS sites (Figs. 5 and 6) suggest that where slopes are directly coupled to the channel, soil moisture conditions are unlikely to favour processes such as denitrification since the water table is usually too deep. It follows therefore that some buffer zone functions cannot work effectively in low-order (i.e. headwater) tributaries where there is only a very narrow floodplain (e.g. Nortcliff and Thornes, 1984) or none at all (e.g. Anderson and Burt, 1978). A functional riparian zone depends on the existence of topographic and soil conditions that conduce, at least seasonally, a high water table. At the risk of sounding tautological, if no functional riparian zone exists, i.e. if slopes are directly coupled to the channel, some buffer zone processes cannot operate effectively. Our results imply that buffer zones have most potential where a floodplain is present. This seems to be borne out by the fact that the only two NICOLAS sites 
showing no nitrate removal were the woodland sites in Romania and UK (Figs. 5 and 6), both of which lack a floodplain. Buffer zone programmes might therefore be most appropriate along the middle-order reaches of a river network since first-order (headwater) tributaries may not have floodplains. On the other hand, on high-order sections of large rivers, the upland areas may be too remote from the channel for buffer zones to have much effect, and intensive farming of very wide floodplains creates its own problems (e.g. in relation to land drainage) when seeking to decouple farmland from the river system (Pinay et al., 1998). Previous studies have shown that, for slopes with deep permeable soils, high subsurface flow is only generated downslope once the soil moisture deficit has been satisfied (Anderson and Burt, 1978; Burt and Butcher, 1985); this pattern was confirmed at all the NICOLAS sites. A combination of high water table and high hydraulic gradient on the slope during winter generates significant subsurface flow into the riparian zone. Provided topography and soil properties in the riparian zone are appropriate, this will sustain a high water table in the riparian zone throughout the winter period. In summer, the hillslope may not be a source of water for the riparian zone, and the water table will fall if not sustained by flow from the adjacent river or lake. As already noted, buffer zone functions such as denitrification can only operate during periods of high water table level and when there are subsurface flows from the hillslope to the riparian zone. Doubtless, there is some buffering of river or lake water when it flows from the river or lake into the riparian zone but this is likely to be of minor importance compared to the buffering of hillslope drainage.

Most studies of hydrological processes in loworder tributaries have, until recently ignored situations where there is a floodplain between the slope and the river channel. The research reported here adds to our knowledge of water table fluctuations within the riparian zones of headwater valleys. We have shown that water table levels within the riparian zone at most NICOLAS sites depend not only on slope discharge, but also on conditions within the riparian zone (topography and soil properties in particular) and in some circumstances (in summer or in floods) on flow into the riparian zone from the adjacent river or lake. Although slope discharge remains important, the adjoining river or lake becomes much more signifi- cant where the riparian zone is flat. The river provides a base level for the water table elevation within the riparian zone, and water table fluctuations further upslope then 'hinge' around this fixed datum. In summer, when slope inputs are minimal, the hydraulic gradient may even reverse, with water seeping into the bank and across the floodplain, for example, at the French and Polish sites. Following the definition of Mertes (1997), this means that the hyporheic zone, where river and ground water mix in the subsurface zone, will extend beyond the channel bank and across the floodplain, even occasionally reaching the foot of neighbouring slopes. At the French site, the recharge of the floodplain in autumn preceded the wetting up of the slope (Fig. 11), and the groundwater ridge (comprising river water) moved right across the floodplain to the footslope. As noted at the start, the riparian zone sensu stricto includes only the bed and banks of the river channel; however, this meaning has been broadened recently to include a wider strip of land bordering the channel. On the basis of our results, this wider definition of riparian zone seems to be legitimate hydrologically, since we can demonstrate a hydrological basis for what has often been a pragmatic decision.

The pattern of floodplain recharge observed at the French site in autumn (Figs. 11 and 12) mirrors that modelled by Bates et al. (2000) and described by Burt et al. (2002) for the much larger floodplain of the River Severn in central England. This involves a reverse groundwater ridge that moves across the floodplain towards the slope during flood events. In summer and early autumn there is little runoff from the adjacent hillslope but later in the autumn, there is significant subsurface flow downslope. At this time, the reverse groundwater ridge generated during inbank floods is not sufficient to interrupt the slope drainage and, once river stage falls, the hydraulic gradient from slope to river is re-established, slowing the flood recession and helping to sustain baseflow between flood events. In winter, when larger out-ofbank flood events are more common, a steep reverse groundwater ridge develops at the base of the slope at the time of peak inundation, preventing hillslope drainage from reaching the floodplain. During the recession, a normal hydraulic gradient is soon reestablished, especially below a hillslope hollow that provides a major source of input to the floodplain. 
Further analysis of the French sites will utilise continuous dipwell data supplied by data loggers to indicate the specific role of flood events, adding detail to the seasonal pattern defined on Figs. 11 and 12.

\section{Implications and conclusions}

It is instructive to invoke concepts from landscape ecology in order to analyse the function and spatial location of riparian buffer zones within the landscape (Malanson, 1993). Forman and Godron (1986) identified three elements of landscapes: a matrix of homogenous land use units (tesserae) that cover most of an area; patches that differ from their surroundings; and, corridors that differ from the matrix on either side. Forman and Godron (1986) emphasise that, not only do riparian corridors occupy a distinct topological position within the landscape, but they also represent a distinct process domain. Naiman and Décamps (1990) have emphasised the role of riparian zones as ecotones: landscape boundaries that physically separate aquatic and terrestrial ecosystems. Ecotones are important regulators of the movement of energy and material across landscapes and through catchments and their dynamic nature and management potential have recently become subjects of great interest. These NICOLAS results will be critical in investigating the potential of riparian zones to act as nitrate buffer zones, limiting the movement of nitrate pollution from farmland into surface watercourses. The hydrological results from the various study sites across Europe suggest that riparian zones in low-order tributaries can indeed provide conditions conducive to denitrification, provided there is an area of flat ground adjacent to the channel. This is confirmed by the fact that nitrate removal was evident at most of the NICOLAS sites (see below). As noted above, it is important that the flat riparian zone is not too narrow; otherwise the water table may not be high enough to allow denitrification to proceed effectively. It is important that riparian soils are not too permeable, or the residence time of soil water will not be long enough for anoxic conditions to develop. On the other hand, it is equally important that riparian soils are not impermeable; otherwise the subsurface flux of nitrate will be too small to be effective (Burt et al., 1999). Also, saturation-excess overland flow will be gener- ated instead of subsurface flow, bypassing the riparian zone and precluding denitrification (Hill, 1993; Cirmo and McDonnell, 1997). It seems likely that the optimal situation will be where the water table remains high throughout the year, yet where significant flow rates can still occur to move large quantities of water through the riparian soils. We hesitate to define a minimum width for nitrate buffer zones, but it is clear from our studies (see, for example, the study of Clément (2001) at the French site), and those at other sites (e.g. Haycock and Burt, 1993; Burt et al., 1999), that denitrification can remove most of the nitrate in influent waters within just a few metres if conditions are optimal. However, the buffer zone may need to be somewhat wider in order that hydrological conditions are optimal for $\mathrm{N}$ removal. Of course, optimal conditions for nitrate removal may not favour retention of other pollutants; for example, sediment deposition is encouraged in dry soils where infiltration of overland flow can take place (Dillaha and Inamdar, 1997). Thus buffer zone design must consider which pollutants take priority at a particular location and some compromise may be necessary where multipurpose buffer zones are required.

Our results also demonstrate a clear seasonality in buffer zone hydrology: in summer, the water table in the riparian zone may well fall below the surface organic horizon, reducing the effectiveness of denitrification owing to limitation in carbon supply. Moreover, at some sites, the hydraulic gradient completely reverses in summer, and until the normal hydraulic gradient is re-established, there can be no buffering of subsurface hillslope runoff, which, fortunately, is of minimal quantity in summer anyway. On the other hand, seepage from river or lake into the riparian zone in summer does increase the overall residence time of water moving through the catchment system and increases the opportunity for nitrate removal; Hillbricht-Ilkowska et al. (1995) make a similar point in relation to phosphorus transport. Overall, this suggests, in relation to denitrification, that riparian buffer zones will be most effective during winter when the water table is high, despite soil temperatures being lower (but not too low to prevent denitrification, at least at the more temperate NICOLAS sites). In summer, uptake by vegetation and the soil microbial biomass might dominate. These processes provide only temporary 
removal of nitrate, although other work within the NICOLAS programme shows that the decay of litter may be sufficiently slow to delay mineralisation until the spring when uptake becomes once again important.

The purpose of this paper is to analyse the hydrology of the NICOLAS sites; work on nitrogen cycling, and other NICOLAS objectives, will be reported elsewhere (but see Pinay and Burt, 2001, for which a website address is listed below). However, some brief comments may be informative. Nitrate elimination occurred at most sites with an efficiency of $5-30 \% \mathrm{~m}^{-1}$ reduction in nitrate concentration, and mostly within the first few tens of metres of the upland-wetland interface. There was no clear pattern of nitrate removal between sites, either on the basis of climate or vegetation cover. Significantly, however, the only two sites not showing any nitrate removal were the woodland buffers in Romania and UK, locations where slopes run straight to the stream (Figs. 5 and 6). For nitrate- $\mathrm{N}$ input concentrations above $5 \mathrm{mg} \mathrm{l}^{-1}$, nitrate reduction efficiency increased with nitrate flux and decreased with nitrate concentration. As expected, this confirms that nutrient export from the upslope area is an important factor and suggests that further scenario modelling using REMM could prove instructive in order to show which sites might offer the greatest nitrate buffering capacity. We have not, as yet, sought to generalise the hydrological results. Despite identical experimental designs, there is probably too much variation between sites (topography, soil, vegetation, etc.) and too few sites (14) to allow much statistical analysis. Further use of REMM would again seem in order, given the model's ability to include both riparian zone characteristics and the upslope inputs.

Finally, in relation to the initial hypotheses proposed above, the following conclusions can be made:

- A number of factors control the development of soil saturation within the riparian zone, of which hillslope discharge is only one. The very existence of a floodplain is crucial in providing a low hydraulic gradient; soil hydraulic conductivity is also important in optimising soil water residence times within the riparian zone (see below). Water level in the adjoining river or lake is also more significant in constraining water table fluctuations within the riparian zone than we originally appreciated. This influence is not confined to flood events, but in summer may extend for long periods of time when there is little or no discharge from adjacent slopes.

- All the floodplains studied displayed a clear annual cycle of water table fluctuation. Nevertheless, climate seems no more important than geomorphology in controlling the range of variation, especially in regard to the summer reversal of hydraulic gradient. However, climate does play its part: it is in winter, when soil moisture deficits have disappeared, that slope discharge becomes the dominant influence on riparian zone hydrology, and it is at this time that the highest water table levels are sustained, favouring denitrification.

- Floodplain alluvium may in some cases be too permeable to sustain high water tables for long periods. On the other hand, if the soil is too impermeable, too little water may flow through to optimise denitrification. Soils of medium hydraulic conductivity in combination with appropriate geomorphology (a flat riparian zone, several tens of metres wide) may provide optimal conditions for denitrification therefore.

- Riparian zones may therefore be most effective in the middle-order sections of river systems where there is a sufficiently wide riparian zone to sustain a high water table and allow buffer zone processes to operate effectively, but not so wide as to completely decouple upland areas from surface water courses.

\section{Acknowledgments}

The results reported here were collected as part of a pan-European project on nitrate buffer zones, the NICOLAS (Nitrogen Control by Landscape Structures in Agricultural Environments) project. This was funded by the European Commission DG XII (Scientific Advisor, H. Barth), grant number ENV4-CT97-0395. We are grateful to two anonymous referees for their very helpful comments. 


\section{References}

Anderson, M.G., Burt, T.P., 1978. The role of topography in controlling throughflow generation. Earth Surface Processes and Landforms 3, 331-344.

Anderson, M.G., Burt, T.P., 1990. Subsurface runoff. In: Anderson, M.G., Burt, T.P. (Eds.), Process Studies in Hillslope Hydrology, Wiley, Chichester, pp. 365-400.

Bates, P.D., Stewart, M.D., Desitter, A., Anderson, M.G., Renaud, J.-P., Smith, J.A., 2000. Numerical simulation of floodplain hydrology. Water Resources Research 36, 2517-2530.

Burt, T.P., 1995. The role of wetlands in runoff generation from headwater catchments. In: Hughes, J.M.R., Heathwaite, A.L. (Eds.), Hydrology and Hydrochemistry of British Wetlands, Wiley, New York, pp. 21-38.

Burt, T.P., 1997. The hydrological role of buffer zones within the drainage basin system. In: Haycock, N.E., Burt, T.P., Goulding, K.W.T., Pinay, G. (Eds.), Buffer Zones: Their Processes and Potential in Water Protection, Quest Environmental, Harpenden, UK, pp. 21-32.

Burt, T.P., Butcher, D.P., 1985. Topographic controls of soil moisture distribution. Journal of Soil Science 36, 469-486.

Burt, T.P., Haycock, N.E., 1996. Linking floodplains to rivers. In: Anderson, M.G., Walling, D.E., Bates, P. (Eds.), Floodplain Processes, Wiley, New York, pp. 461-492.

Burt, T.P., Matchett, L.S., Goulding, K.W.T., Webster, C.P., Haycock, N.E., 1999. Denitrification in riparian buffer zones: the role of floodplain sediments. Hydrological Processes 13, $1451-1463$

Burt, T.P., Stewart, M.D., Bates, P.D., Claxton, A.J., Anderson, M.G., Price, D.A., 2002. Water table fluctuations within the floodplain of the River Severn, England. Journal of Hydrology 262, 1-20.

Buttle, J.M., Sami, K., 1992. Testing the groundwater ridging hypothesis of streamflow generation during snowmelt in a forested catchment. Journal of Hydrology 135, 53-72.

Cirmo, C.P., McDonnell, J.J., 1997. Linking the hydrologic and biogeochemical controls of nitrogen transport in near-stream zones of temperate-forested catchments: a review. Journal of Hydrology 199, 88-120.

Clément, J.C., 2001. Les zones humides de fonds de vallée et la régulation des pollutions azotées diffuses. Unpublished $\mathrm{PhD}$ Thesis, Université de Rennes 1, France.

Dillaha, T.A., Inamdar, S.P., 1997. Buffer zones as sediment traps or sources. In: Haycock, N.E., Burt, T.P., Goulding, K.W.T., Pinay, G. (Eds.), Buffer Zones: their Processes and Potential in Water Protection, Quest Environmental, Harpenden, UK, pp. 33-42.

Forman, R.T.T., Godron, M., 1986. Landscape Ecology, Wiley, New York.

Gillham, R.W., 1984. The capillary fringe and its effect on watertable response. Journal of Hydrology 67, 307-324.

Haycock, N.E., Burt, T.P., 1993. Role of floodplain sediments in reducing the nitrate concentration of subsurface run-off: a case study in the Cotswolds, UK. Hydrological Processes 7, 287-295.

Haycock, N.E., Pinay, G., 1993. Groundwater nitrate dynamics in grass and poplar vegetated riparian buffer strips during the winter. Journal of Environmental Quality 22, 273-278.

Haycock, N.E., Burt, T.P., Goulding, K.W.T., Pinay, G., 1997. Buffer Zones: their Processes and Potential in Water Protection, Quest Environmental, Harpenden, UK.

Hill, A.R., 1990. Groundwater flow paths in relation to nitrogen chemistry in the near-stream zone. Hydrobiologia 206, 39-52.

Hill, A.R., 1993. Nitrogen dynamics of storm runoff in the riparian zone of a forested watershed. Biogeochemistry 14, 209-224.

Hill, A.R., 1997. The potential role of in-stream and hyporheic environments as buffer zones. In: Haycock, N.E., Burt, T.P., Goulding, K.W.T., Pinay, G. (Eds.), Buffer Zones: their Processes and Potential in Water Protection, Quest Environmental, Harpenden, UK, pp. $115-127$.

Hillbricht-Ilkowska, A., Ryzkowski, L., Sharpley, A.N., 1995. Phosphorus transfers and landscape structure: riparian sites and diversified land use patterns. In: Tiessen, H., (Ed.), Phosphorus in the Global Environment, SCOPE 54, Wiley, New York, pp. 201-227.

Knowles, R., 2000. Nitrogen cycle, Encyclopedia of Microbiology, vol. 3. Academic Press, New York, pp. 379-391.

Kondolf, G.M., Maloney, L.M., Williams, J.G., 1987. Effects of bank storage and well pumping on baseflow. Carmel River, Monterrey County, California. Journal of Hydrology 91, 351-369.

Lowrance, R., Altier, L.S., Williams, R.G., Inamdar, S.P., Bosch, D.D., Hubbard, R.K., Thomas, D.L., 2000. REMM: the riparian ecosystem management model. Journal of Soil and Water Conservation 55, 27-36.

Malanson, G.P., 1993. Riparian Landscapes, Cambridge Studies in Ecology, 296pp.

Mertes, L.A.K., 1997. Documentation and significance of the perirheic zone on inundated floodplains. Water Resources Research 33, 1749-1762.

Naiman, R.J., Décamps, H., 1990. The Ecology and Management of the Terrestrial-Aquatic Ecotone, Parthenon Press, Paris, UNESCO.

Nortcliff, S., Thornes, J.B., 1984. Floodplain response of a small tropical stream. In: Walling, D.E., Burt, T.P. (Eds.), Catchment Experiments in Fluvial Geomorphology', Geo Books, pp. 73-86.

Peterjohn, W.T., Correll, D.L., 1984. Nutrient dynamics in an agricultural watershed: observations on the role of a riparian forest. Ecology 65 (5), 1466-1475.

Pinay, G., Burt. T.P., 2001. Nitrogen control by landscape structures. Final report, grant ENV4-CT97-0395, European Commission (DG X11), Brussels. http://www.qest.demon.co. uk/nicolas/nicolas.htm/.

Pinay, G., Ruffinoni, C., Wondzell, S., Gazelle, F., 1998. Change in groundwater nitrate concentration in a large river floodplain: denitrification, uptake, or mixing ? Journal of North America Benthological Society 17 (2), 179-189.

Squillace, P.J., 1996. Observed and simulated movement of bank storage water. Groundwater 34, 121-134. 
Tansley, A.G., 1911. Types of British Vegetation, Cambridge University Press, Cambridge.

Waddington, J.M., Roulet, N., Hill, A.R., 1993. Runoff mechanisms in a forested groundwater discharge wetland. Journal of Hydrology 147, 37-60.
Weyman, D.R., 1973. Measurement of the downslope flow of water in a soil. Journal of Hydrology 20, 267-288.

Winter, T.C., 1995. Recent advances in understanding the interaction of groundwater and surface water. Reviews of Geophysics 33, 985-994. 